\title{
Intrahepatic Bile Duct Cancer pNX TNM
} Finding v8

National Cancer Institute

\section{Source}

National Cancer Institute. Intrahepatic Bile Duct Cancer pNX TNM Finding v8. NCI

Thesaurus. Code C134600.

Intrahepatic bile duct cancer in which the regional lymph node(s) cannot be assessed.

(from AJCC 8th Ed.) 